Basil F. Matta MB FRCA, Arthur M. Lam MD FRCPC, Teresa S. Mayberg MD

\title{
The influence of arterial oxygenation on cerebral venous oxygen saturation during hyperventilation
}

Cerebral venous oxygen desaturation may occur when hyperventilation is employed during neurosurgical procedures. In this study, we examined the effect of arterial hyperoxia $\left(\mathrm{PaO}_{2}>\right.$ $200 \mathrm{mmHg}$ ) on jugular bulb venous oxygen tension $\left(\mathrm{PjNO}_{2}\right.$, saturation $\left(\mathrm{SjvO}_{2}\right)$ and content $\left(\mathrm{CjvO}_{2}\right)$ in 12 patients undergoing anaesthesia for neurosurgical procedures. Under stable anaesthetic conditions, the inspired oxygen fraction $\left(\mathrm{FrO}_{2}\right)$ was varied to give four different levels of arterial oxygen tension $\left(\mathrm{PaO}_{2} 100-200,201-300,301-400\right.$, and $\left.>400 \mathrm{~mm} \mathrm{Hg}\right)$, at two levels of controlled hyperventilation ( $\mathrm{PaCO}_{2} 25$ and $30 \mathrm{~mm} \mathrm{Hg}$ ). In five patients, a transcranial Doppler probe was used to insonate the middle cerebral artery throughout the study period. Regression lines were constructed for each patient for the $\mathrm{PjvO}_{2}$, $\mathrm{SjvO}_{2}$ and the corresponding $\mathrm{PaO}_{2}$ for both levels of $\mathrm{PaCO}_{2}$ (all $\mathrm{PjvO}_{2} \mathrm{PaO}_{2}$ and $\mathrm{SjvO}_{2} \mathrm{PaO}_{2}$ regression lines $\mathrm{r}^{2}>0.85$, $P<0.0001$ ). From these lines we calculated the $\mathrm{PjvO}_{2}, \mathrm{SjvO}_{2}$ and $\mathrm{CjvO}_{2}$ at $\mathrm{PaO}_{2}$ of 100,250 and $400 \mathrm{mmHg}$, at each level of $\mathrm{PaCO}_{2}$ for each patient. At $\mathrm{PaCO}_{2}$ of $25 \mathrm{mmHg}$, hyperoxaemia increased $\mathrm{PjvO}_{2}$ (from $27.6 \pm 1.1 \mathrm{mmHg}$ at $\mathrm{PaO}_{2}$ of $100 \mathrm{mmHg}$ to $30.6 \pm 1.4$ and $33.6 \pm 1.8 \mathrm{~mm} \mathrm{Hg}$ at $\mathrm{PaO}_{2}$ of 250 and $400 \mathrm{mmHg}$ respectively) and $\mathrm{SjvO}_{2}$ (from $54 \pm$ $3 \%$ at $\mathrm{PaO}_{2}$ of $100 \mathrm{mmHg}$ to $60 \pm 3$ and $65 \pm 3 \%$ at $\mathrm{PaO}_{2}$ of 250 and $400 \mathrm{mmHg}$ respectively, $P<0.05$ ). Hyperoxaemia had a similar effect on $\mathrm{SjvO}_{2}$ and $\mathrm{PjvO}_{2}$ at a $\mathrm{PaCO}_{2}$ of 30

\section{Key words}

ANAESTHESIA: neurosurgical;

BLOOD FLOW: velocity, cerebral;

EQUIPMENT: Doppler

MEASUREMENT TECHNIQUES: Doppler ultrasound;

MONITORING: oxygen, jugular venous;

OXYGEN: consumption, brain.

From the Department of Anesthesiology, University of Washington School of Medicine, Harborview Medical Center, Seattle, Washington 98104, USA.

Address correspondence to: Dr. Arthur M. Lam, Department of Anesthesiology, Harborview Medical Center, 325 Ninth Avenue, ZA-14, Seattle WA 98104.

Accepted for publication 11th June, 1994. $m m \mathrm{Hg}$. For a given $\mathrm{PaO}_{2}$, the $\mathrm{PjvO}_{2}, \mathrm{SjvO}_{2}$ and $\mathrm{CjvO}_{2}$ were lower at $\mathrm{PaCO}_{2}$ of $25 \mathrm{mmHg}$ than at a $\mathrm{PaCO}_{2}$ of $30 \mathrm{~mm} \mathrm{Hg}$ $(P<0.01)$. The predicted $\mathrm{CjvO}_{2}$ based on the increased $\mathrm{PaO}_{2}$ and an unchanged cerebral metabolic rate for oxygen was also calculated and was no different from the measured $\mathrm{CjvO}_{2}$ with hyperoxia. Middle cerebral artery flow velocity did not change with hyperoxia, but decreased with hypocapnia ( $48 \pm 7$ to 35 $\pm 4 \mathrm{~cm} \cdot \mathrm{sec}^{-1}, P<0.01$ ). We conclude that hyperoxia during acute hyperventilation in the anaesthetized patient improves oxygen delivery to the cerebral circulation, as measured by a higher cerebral venous oxygen content and saturation. An increased $\mathrm{PaO}_{2}$ should be considered for those patients in whom aggressive hyperventilation is contemplated.

La désaturation veineuse centrale peut survenir pendant lhyperventilation réalisée au cours dinterventions neurochirurgicales. Nous avons étudié les répercussions de l'hyperoxémie $\left(\mathrm{PaO}_{2}>200 \mathrm{mmHg}\right.$ ) sur la tension en oxygène du bulbe jugulaire $\left(\mathrm{PjvO}_{2}\right)$, sa saturation $\left(\mathrm{SjvO}_{2}\right)$ et son contenu $\left(\mathrm{CjvO}_{2}\right)$ chez 12 patients soumis à une anesthésie générale pour une intervention neurochirugicale. Sous des conditions stables d'anesthésie, la fraction en oxygène inspiré $\left(\mathrm{FIO}_{2}\right)$ a été variée pour produire quatre niveaux diffërents de tension artérielle en oxygène $\left(\mathrm{PaO}_{2} 100-200,201-300,301-400\right.$ et $\left.>400 \mathrm{~mm} \mathrm{Hg}\right)$ à deux niveaux dhyperventilation ( $\mathrm{PaCO}_{2} 25$ et $\left.30 \mathrm{~mm} \mathrm{Hg}\right)$. Une sonde de Döppler intracrânienne a été insérée à cinq patients pour explorer l'artère méningée moyenne. $A$ chaque patient, nous avons construit des lignes de régression de la $\mathrm{PjvO}_{2}$, de la $\mathrm{SjvO}_{2}$ pour la $\mathrm{PaO}_{2}$ correspondante, aux deux niveaux de $\mathrm{PaCO}_{2}$ (toutes les lignes de régression $\mathrm{PjvO}_{2}-\mathrm{PaO}_{2}$ et $\mathrm{SjvO}_{2}$ $\left.\mathrm{PaO}_{2} \mathrm{r}^{2}>0,85, \mathrm{P}<0,0001\right)$. A partir de ces lignes, nous avons calculé chez chaque patient la $\mathrm{PjvO}_{2}$, la $\mathrm{SjNO}_{2}$ et le $\mathrm{CjvO}_{2}$ aux $\mathrm{PaO}_{2}$ de 100, 250 et $400 \mathrm{mmHg}$, pour chaque niveau de $\mathrm{PaCO}_{2}$. A la $\mathrm{PaCO}_{2}$ de $25 \mathrm{mmHg}$, lhyperoxémie a augmenté la $\mathrm{PjuO}_{2}$ (de 27,6 $\pm 1,1 \mathrm{mmHg}$ pour une $\mathrm{PaO}_{2}$ de $100 \mathrm{~mm} \mathrm{Hg}$ à $30 \pm 1,4$ et $33,6 \pm 1,8 \mathrm{mmHg}$ aux $\mathrm{PaO}_{2}$ de 250 et 400 mmHg respectivement, $P<0,05)$. Lhyperoxémie a eu le même effet sur la $\mathrm{SjvO}_{2}$ et la $\mathrm{PjvO}_{2}$ à la $\mathrm{PaCO}_{2}$ de $30 \mathrm{mmHg}$. Pour une $\mathrm{PaO}_{2}$ donnée, la $\mathrm{PjvO}_{2}$, la $\mathrm{SjvO}_{2}$ et le $\mathrm{CjvO}_{2}$ ont été plus bas à la $\mathrm{PaCO}_{2}$ de $25 \mathrm{mmHg}$ qu'à celle de $30 \mathrm{mmHg}(P<$ 
0,01). $\mathrm{La} \mathrm{CjvO}_{2}$ prédite lorsque la $\mathrm{PaO}_{2}$ augmente et que le taux métabolique cérébral demeure inchangé a aussi été calculée et n'a pas été trouvée différente de la $\mathrm{Cj}_{\mathrm{j}} \mathrm{O}_{2}$ mesurée en hyperoxémie. La vélocité du courant sanguin de l'artère cérébrale moyenne n'a pas changé avec l'hyperoxémie mais a diminué avec l'hypocarbie (de $48 \pm 7$ à $35 \pm 4 \mathrm{~cm} \cdot \mathrm{sec}^{-1}$, $P<0,01$ ). Nous concluons que chez le sujet anesthésié, lhyperoxie produite pendant une hyperventilation aiguë améliore l'apport en oxygène de la circulation cérébrale, comme l'ont montré l'augmentation du contenu veineux cérébral et de la saturation en oxygène. On doit envisager d'augmenter la $\mathrm{PaO}_{2}$ des patients quil faut ventiler agressivement.

Acute hyperventilation decreases cerebral blood flow (CBF). ${ }^{1,2}$ It causes electroencephalographic slowing consistent with cerebral ischaemia ${ }^{3}$ and an increase in brain tissue and cerebrospinal fluid lactate concentrations, ${ }^{4}$ that can be reversed with the administration of hyperbaric oxygen. ${ }^{3,5}$ Despite this potentially undesirable effect on CBF, hyperventilation reduces cerebral blood volume and intracranial pressure (ICP), and may improve cerebral perfusion pressure (CPP) in some patients. Consequently, hyperventilation provides improved operating conditions and is frequently used during neurosurgical procedures. Intraoperative surgical requirements (reduction of brain bulk) may necessitate marked hyperventilation at the risk of causing cerebral ischaemia. It would be desirable if hyperventilation could be employed to provide improved operating conditions and/or reduce ICP without the accompanying reduction in oxygen delivery to the brain. Increasing the arterial oxygen tension and content may allow greater oxygen delivery to the brain during this vulnerable period. However, hyperoxygenation has been shown to cause cerebral vasoconstriction which may negate the potential improvement in oxygen delivery. ${ }^{6}$ To clarify this interaction, we studied the effect of hyperoxia at two levels of $\mathrm{PaCO}_{2}$ on the cerebral venous oxygen content in 12 patients undergoing anaesthesia for neurosurgery.

\section{Methods}

The study was approved by the University of Washington Human Subjects Review Committee. After obtaining written consent, 12 patients, ASA physical status 1 or 2 , who were about to undergo craniotomies for various elective neurosurgical procedures (nine cerebral aneurysms and three intracranial tumours) were studied. With all routine monitors in place (ECG, arterial catheter, pulse oximetry), patients received a standardized anaesthetic consisting of $i \mathrm{v}$ midazolam 1-2 mg, thiopentone 3-5 $\mathrm{mg} \cdot \mathrm{kg}^{-1}$, fentanyl bolus $3 \mu \mathrm{g} \cdot \mathrm{kg}^{-1}$ followed by infusion $3 \mu \mathrm{g} \cdot \mathrm{kg}^{-1} \cdot \mathrm{hr}^{-1}$ and vecuronium $0.1 \mathrm{mg} \cdot \mathrm{kg}^{-1}$. After the trachea was intubated, the lungs were mechanically ventilated to normocapnia with an air/oxygen mixture and anaesthesia was maintained with low dose isoflurane (end-tidal $0.5-1.0 \%$ ). Using an aseptic technique described previously, ${ }^{7}$ we inserted a 16 -gauge, $13.3 \mathrm{~cm}$ retrograde jugular bulb catheter (Angiocath ${ }^{\circledR}$, Becton and Dickinson) in all patients without complication. The catheter was inserted contralateral to the operative site and the position of the catheter was checked radiographically and was satisfactory in all patients studied (tip of the catheter was at the level of and just medial to the mastoid bone). In five patients, surgical conditions permitted the measurement of cerebral blood flow velocity from the middle cerebral artery (MCA) ipsilateral to the jugular venous bulb catheter throughout the study period. The MCA was insonated with a $2 \mathrm{MHz}$ transcranial Doppler probe (Medasonics, Fremont, CA, USA) through the temporal window, using a technique previously described. ${ }^{8}$ A low profile attachment was used to secure the probe in position so that the angle of insonation remained constant throughout the study. Doppler signals were identified and measured at $45-50 \mathrm{mmHg}$. The shift in frequency spectra of the Doppler signals converted into mean flow velocity ( $\mathrm{Vmca}$ ) were displayed on a video monitor. Flow velocities were recorded at end-expiration.

Under stable anaesthetic and surgical conditions, and at least $\mathbf{3 0}$ min after mannitol administration, the patients' lungs were hyperventilated to a $\mathrm{PaCO}_{2}$ of $25 \mathrm{mmHg}$ $( \pm 1)$. A 15-min period of stabilization was allowed at that $\mathrm{PaCO}_{2}$. The $\mathrm{FIO}_{2}$ was then varied to achieve four levels of $\mathrm{PaO}_{2}: 100-200,201-300,301-400$ and $>400$ $\mathrm{mmHg}$. After a further $15 \mathrm{~min}$ stabilization at each $\mathrm{PaO}_{2}$ level, arterial and jugular venous blood gases were drawn (at a rate of $<2 \mathrm{ml} \cdot \mathrm{min}^{-1}$ ) and Vmca (in five patients) was recorded at each level of $\mathrm{PaO}_{2}$. The $\mathrm{PaCO}_{2}$ was then increased to $30 \mathrm{mmHg}( \pm 1)$ and the same procedure repeated. The tidal volume and respiratory rate were altered in such a manner so as to maintain airway pressure constant, thus minimizing the effects on venous return and cardiac output. The study sequence was randomized so that half of the patients were studied at a $\mathrm{PaCO}_{2}$ of $30 \mathrm{mmHg}$ first and the other half were studied initially at a $\mathrm{PaCO}_{2}$ of $25 \mathrm{mmHg}$. The blood samples were analyzed using an automated blood gas analyzer (Nova Biomedical 9, Waltham, MA, USA).

Regression lines were constructed for each patient for the $\mathrm{PjvO}_{2}, \mathrm{SjvO}_{2}$ and the corresponding $\mathrm{PaO}_{2}$ for both levels of $\mathrm{PaCO}_{2}$. From these lines we calculated the $\mathrm{PjvO}_{2}, \mathrm{SjvO}_{2}, \mathrm{CjvO}_{2}$ and the arteriovenous oxygen content difference $\left(\mathrm{AVDO}_{2}\right)$ at $\mathrm{PaO}_{2}$ of 100,250 , and 400 $\mathrm{mmHg}$, at each level of $\mathrm{PaCO}_{2}$ for each patient. The arterial and venous oxygen contents $\left(\mathrm{CaO}_{2}, \mathrm{CjvO}_{2}\right)$ and $\mathrm{AVDO}_{2}$ were calculated from the arterial $\mathrm{PO}_{2}$ and sat- 
uration, and jugular venous $\mathrm{O}_{2}$ tension and saturation using the equation:

$$
\begin{aligned}
\operatorname{AVDO}_{2}= & \text { arterial } \mathrm{O}_{2} \text { content }\left(\mathrm{CaO}_{2}\right) \\
\quad-\text { jugular venous } \mathrm{O}_{2} \text { content }(\mathrm{CjvO}) & \\
= & \left.\mathrm{Hgb} \times 1.39 \times \mathrm{SaO}_{2}+0.003 \times \mathrm{PaO}_{2}\right) \\
& \quad-\left(\mathrm{Hgb} \times 1.39 \times \mathrm{SjvO}_{2}+0.003 \times \mathrm{PjvO}_{2}\right) .
\end{aligned}
$$

The data were analyzed using two-way analysis of variance for repeated measures. We considered a $P$ value $<0.05$ statistically significant.

To assess the magnitude of cerebral vasoconstriction secondary to hyperoxygenation, which would result in a $\mathrm{CjvO}_{2}$ value lower than expected based on the increase in oxygen delivery, we derived the predicted $\mathrm{CjvO}_{2}$ and compared it with the measured $\mathrm{CjvO}_{2}$. To do this, we considered $\mathrm{PaO}_{2}$ of $100 \mathrm{mmHg}$ to be normoxia, and calculated the corresponding $\mathrm{AVDO}_{2}$. Assuming an unchanged cerebral metabolic rate (therefore an unchanged $\mathrm{ADVO}_{2}$ if CBF remains constant), we then calculated the $\mathrm{CjvO}_{2}$ at $\mathrm{PaO}_{2}$ of 250 and $400 \mathrm{mmHg}$. Thus the predicted $\mathrm{CjvO}_{2}$ at $\mathrm{PaO}_{2}$ of $250 \mathrm{mmHg}=\mathrm{CaO}_{2}$ at $\mathrm{PaO}_{2}$ of $250 \mathrm{mmHg}-\mathrm{AVDO}_{2}$ at $\mathrm{PaO}_{2}$ of $100 \mathrm{mmHg}$ and the predicted $\mathrm{CjvO}_{2}$ at $\mathrm{PaO}_{2}$ of $400 \mathrm{mmHg}=\mathrm{CaO}_{2}$ at $\mathrm{PaO}_{2}$ of $400 \mathrm{mmHg}-\mathrm{AVDO}_{2}$ at $\mathrm{PaO}_{2}$ of $100 \mathrm{mmHg}$. The predicted values were then compared with the measured values using paired $t$ test.

\section{Results}

The patient data are shown in Table I.

There was no change in the patients' body temperature $\left(36 \pm 0.5^{\circ} \mathrm{C}\right)$, mean arterial pressure $(75 \pm 5 \mathrm{mmHg})$ or heart rate $(75 \pm 10 \mathrm{bpm})$ throughout the study. The $\mathrm{SjvO}_{2}$ vs $\mathrm{PaO}_{2}$ mean regression coefficients for patients at $\mathrm{PaCO}_{2}$ of 25 and $30 \mathrm{mmHg}$ were $0.035 \pm 0.01 \%$ $\mathrm{mmHg}^{-1}, 0.85<\mathrm{r}^{2}<0.996(P<0.001)$, and 0.038 $\pm 0.01 \% \mathrm{mmHg}^{-1}, 0.840<\mathrm{r}^{2}<0.998(P<0.001)$, respectively.

Hyperoxia increased jugular venous oxygen tension, saturation and content, at both levels of $\mathrm{PaCO}_{2}(P<$ 0.05) (Figures 1 and 2). For a given $\mathrm{PaO}_{2}$, the $\mathrm{SjvO}_{2}$, $\mathrm{PjvO}_{2}$ and $\mathrm{CjvO}_{2}$ were higher at a $\mathrm{PaCO}_{2}$ of $30 \mathrm{mmHg}$ than at a $\mathrm{PaCO}_{2}$ of $25 \mathrm{mmHg}(P<0.01)$ (Tables II and III).

At a $\mathrm{PaCO}_{2}$ of $25 \mathrm{mmHg}$, four patients at $\mathrm{PaO}_{2}$ of $100 \mathrm{mmHg}$ and two patients at $\mathrm{PaO}_{2}$ of $250 \mathrm{mmHg}$ had $\mathrm{SjvO}_{2}<50 \%$, but no patients at $\mathrm{PaO}_{2}$ of $400 \mathrm{mmHg}$ had $\mathrm{SjvO}_{2}<50 \%$. At a $\mathrm{PaCO}_{2}$ of $30 \mathrm{mmHg}$, one patient at $\mathrm{PaO}_{2}$ of $100 \mathrm{mmHg}$ had $\mathrm{SjvO}_{2}<50 \%$ but no patient at $\mathrm{PaO}_{2}$ of 250 and $400 \mathrm{mmHg}$ had $\mathrm{SjvO}_{2}<50 \%$.

In the five patients monitored with the transcranial Doppler, Vmca did not change with hyperoxia at either level of $\mathrm{PaCO}_{2}$. Cerebral blood flow velocity increased from $35 \pm 4.0 \mathrm{~cm} \cdot \mathrm{sec}^{-1}$ at a $\mathrm{PaCO}_{2}$ of $25 \mathrm{mmHg}$ to
TABLE I Patient data

\begin{tabular}{ll}
\hline Patient $n=12$ & Mean, SD \\
\hline Age, yr & 51,12 \\
Weight, kg & 72,7 \\
Sex (M:F) & $6: 6$ \\
Haemoglobin $\mathrm{g} \cdot \mathrm{dl}^{-1}$ & $11.9,1.2$ \\
\hline
\end{tabular}

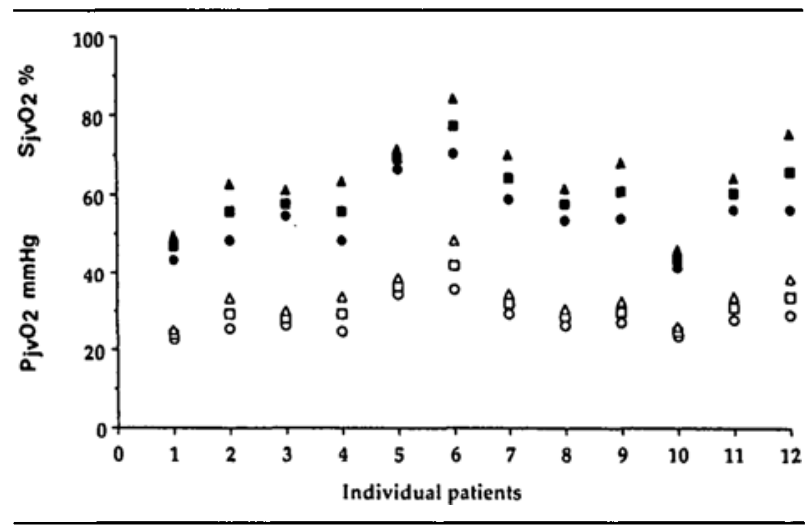

FIGURE $1 \quad \mathrm{SjvO}_{2}$ and $\mathrm{PjvO}_{2}$ at $\mathrm{PaCO}_{2}$ of $25 \mathrm{mmHg}$. $O \mathrm{SjvO}_{2}$ at $\mathrm{PaO}_{2}$ of $100 \mathrm{mmHg}$; $\mathrm{SjvO}_{2}$ at $\mathrm{PaO}_{2}$ of $250 \mathrm{mmHg}, \triangle \mathrm{SjvO} \mathrm{O}_{2}$ at $\mathrm{PaO}_{2}$ of $400 \mathrm{mmHg}$; $\mathrm{OPjvO}_{2}$ at $\mathrm{PaO}_{2}$ of $100 \mathrm{mmHg}$; $\square \mathrm{PjvO}_{2}$ at $\mathrm{PaO}_{2}$ of $250 \mathrm{mmHg} ; \triangle \mathrm{PjvO}_{2}$ at $\mathrm{PaO}_{2}$ of $400 \mathrm{mmHg}$

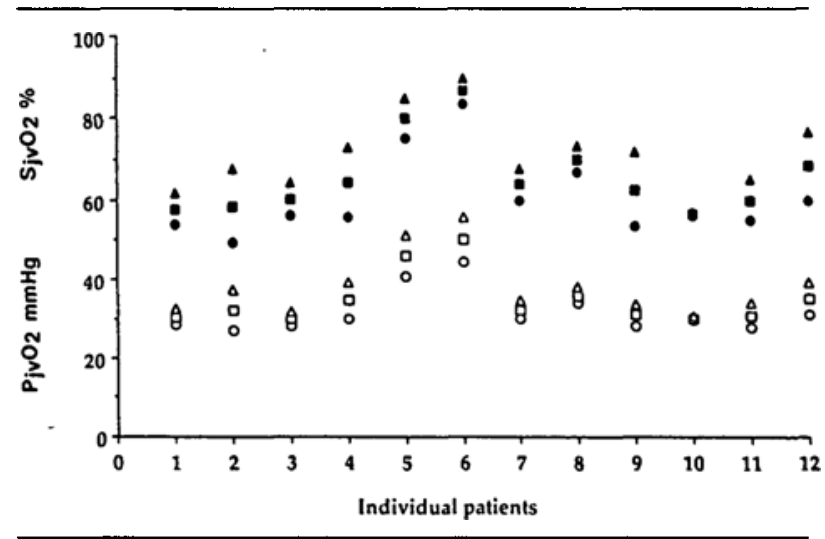

FIGURE $2 \quad \mathrm{SjvO}_{2}$ and $\mathrm{PjvO}_{2}$ at $\mathrm{PaCO}_{2}$ of $30 \mathrm{mmHg}$. $9 \mathrm{SjvO}$ at $\mathrm{PaO}_{2}$ of $100 \mathrm{mmHg}$; $\mathrm{SjvO}_{2}$ at $\mathrm{PaO}_{2}$ of $250 \mathrm{mmHg}, \triangle \mathrm{SjvO}_{2}$ at $\mathrm{PaO}_{2}$ of $400 \mathrm{mmHg}$; $\mathrm{OPjvO}_{2}$ at $\mathrm{PaO}_{2}$ of $100 \mathrm{mmHg}$; $\square \mathrm{PjvO}_{2}$ at $\mathrm{PaO}_{2}$ of $250 \mathrm{mmHg} ; \triangle \mathrm{PjvO}_{2}$ at $\mathrm{PaO}_{2}$ of $400 \mathrm{mmHg}$.

$48 \pm 7 \mathrm{~cm} \cdot \mathrm{sec}^{-1}$ at a $\mathrm{PaCO}_{2}$ of $30 \mathrm{mmHg}(P<0.01)$ (Table II). The measured $\mathrm{CjvO}_{2}$ at hyperoxic $\mathrm{PaO}_{2}\left(\mathrm{PaO}_{2}\right.$ 250 and $400 \mathrm{mmHg}$ ) was not different from the predicted $\mathrm{CjvO}_{2}$ (Table III).

\section{Discussion}

The use of hyperventilation during neurosurgical procedures can result in cerebral venous oxygen desaturation (defined as jugular bulb venous oxygen saturations less 
TABLE II The effect of hyperoxia at two levels of $\mathrm{PaCO}_{2}$ on $\mathrm{SjvO}_{2}$ and $\mathrm{PjvO}_{2}$

\begin{tabular}{|c|c|c|c|c|c|c|}
\hline \multirow[b]{2}{*}{$\begin{array}{l}\mathrm{PaO} \\
\mathrm{mmHg}\end{array}$} & \multicolumn{3}{|c|}{$\mathrm{PaCO}_{2}=25 \mathrm{mmHg}$} & \multicolumn{3}{|c|}{$\mathrm{PaCO}_{2}=30 \mathrm{~mm} \mathrm{Hg}$} \\
\hline & $\begin{array}{l}\mathrm{SjvO}_{2} \%^{*} \\
(n=12)\end{array}$ & $\begin{array}{l}\mathrm{PjvO}_{2} \mathrm{mmHg} \dagger \\
(n=12)\end{array}$ & $\begin{array}{l}V m c a \mathrm{~cm} / \mathrm{sec} \ddagger \\
(n=5)\end{array}$ & $\begin{array}{l}\mathrm{SjvO}_{2} \%^{*} \\
(n=12)\end{array}$ & $\begin{array}{l}\mathrm{PjvO}_{2} \mathrm{mmHg} \dagger \\
(n=12)\end{array}$ & $\begin{array}{l}\text { Vmca cm/sec } \ddagger \\
(n=5)\end{array}$ \\
\hline 100 & $54 \pm 3 \S$ & $27.6 \pm 1.19$ & $35 \pm 4$ & $61 \pm 3 \S$ & $31.6 \pm 1.6 \pi$ & $48 \pm 7$ \\
\hline 250 & $60 \pm 3 \S$ & $30.6 \pm 1.4 \rrbracket$ & $35 \pm 4$ & $66 \pm 3 \S$ & $34.9 \pm 1.99$ & $48 \pm 7$ \\
\hline 400 & $65 \pm 3 \S$ & $33.6 \pm 1.8 \pi$ & $35 \pm 4$ & $71 \pm 3 \S$ & $38.3 \pm 2.2$ & $48 \pm 7$ \\
\hline
\end{tabular}

All values are mean $\pm \mathrm{SE}$.

*The difference between $\mathrm{SjvO}_{2}$ at a $\mathrm{PaCO}_{2}$ of $25 \mathrm{mmHg}$ and $\mathrm{SjvO}_{2}$ at a $\mathrm{PaCO}_{2}$ of $30 \mathrm{mmHg}$ is statistically significant at $P<0.01$.

tThe difference between $\mathrm{PjvO}_{2}$ at $\mathrm{PaCO}_{2}$ of $25 \mathrm{mmHg}$ and $\mathrm{PjvO}_{2}$ at $\mathrm{PaCO}_{2}$ of $30 \mathrm{mmHg}$ is statistically significant at $P<0.01$.

¥The difference between CBFV at $\mathrm{PaCO}_{2}$ of $25 \mathrm{mmHg}$ and CBFV at $\mathrm{PaCO}_{2}$ of $30 \mathrm{mmHg}$ is statistically significant at $P<0.01$.

§The difference between $\mathrm{SjvO}_{2}$ at $\mathrm{PaO}_{2}$ of 100,250 and $400 \mathrm{mmHg}$ is statistically significant at $P<0.05$.

ףThe difference between $\mathrm{PjvO}_{2}$ at $\mathrm{PaO}_{2}$ of 100,250 and $400 \mathrm{mmHg}$ is statistically significant at $P<0.05$.

TABLE III The effect of hyperoxia at two levels of $\mathrm{PaCO}_{2}$ on jugular venous oxygen content: predicted $\left[\mathrm{CjvO}_{2}(\mathrm{p})\right]$ and measured $\left[\mathrm{CjvO} \mathrm{O}_{2}(\mathrm{~m})\right]$

\begin{tabular}{|c|c|c|c|c|}
\hline \multirow[b]{2}{*}{$\begin{array}{l}\mathrm{PaO}_{2} \\
\mathrm{mmHg}\end{array}$} & \multicolumn{2}{|c|}{$\mathrm{PaCO}_{2}=25 \mathrm{mmHg}$} & \multicolumn{2}{|c|}{$\mathrm{PaCO}_{2}=30 \mathrm{~mm} \mathrm{Hg}$} \\
\hline & $\begin{array}{l}\mathrm{CjvO}_{2}(m)^{*} \\
\text { vol\% }\end{array}$ & $\begin{array}{l}\mathrm{CjNO}_{2}(p) \dagger \\
\text { vol\% }\end{array}$ & $\begin{array}{l}\mathrm{CjvO}_{2}(\mathrm{~m})^{*} \\
\text { vol\% }\end{array}$ & $\begin{array}{l}\mathrm{CjNO}_{2}(p) \dagger \\
\text { Vol\% }\end{array}$ \\
\hline 100 & $8.95 \pm 0.48 \ddagger$ & $8.95 \pm 0.48 \ddagger$ & $9.98 \pm 0.53 \ddagger$ & $9.98 \pm 0.53 \ddagger$ \\
\hline 250 & $9.78 \pm 0.45 \ddagger$ & $9.73 \pm 0.49 \ddagger$ & $10.86 \pm 0.50 \ddagger$ & $10.76 \pm 0.53 \ddagger$ \\
\hline 400 & $10.63 \pm 0.47 \ddagger$ & $10.18 \pm 0.50 \ddagger$ & $11.77 \pm 0.54 \ddagger$ & $11.22 \pm 0.54 \ddagger$ \\
\hline
\end{tabular}

All values are mean $\pm \mathrm{SE}$.

*The difference between the measured $\mathrm{CjvO}_{2}$ at $\mathrm{PaCO}_{2}$ of 25 and $\mathrm{CjvO}_{2}$ at $\mathrm{PaCO}_{2}$ of $30 \mathrm{mmHg}$ is statistically significant at $P<0.05$.

TThe difference between the predicted $\mathrm{CjvO}_{2}$ at $\mathrm{PaCO}_{2}$ of 25 and $\mathrm{CjvO}_{2}$ at $\mathrm{PaCO}_{2}$ of $30 \mathrm{mmHg}$ is statistically significant at $P<0.05$.

\$The difference between $\mathrm{CjvO}_{2}$ at $\mathrm{PaO}_{2}$ of 100,250 and $400 \mathrm{mmHg}$ is statistically significant at $P<0.05$.

than $50 \%$ ) in up to $40 \%$ of patients undergoing neurosurgery. ${ }^{7}$ Although the clinical importance of this intraoperative desaturation remains unclear, at best it is indicative of increased extraction of oxygen with a decreased margin of safety, and at worst, indicative of limited oxygen supply with impending tissue hypoxia. Moreover, the use of hyperventilation in patients with severe head injury has been shown to cause cerebral oligaemia ${ }^{9}$ which may lead to a worse neurological outcome. ${ }^{10,11}$

Despite this potential adverse effect, hyperventilation can reduce CBF, cerebral blood volume and intracranial pressure (ICP), and may improve cerebral perfusion pressure (CPP) in some patients. In addition, hyperventilation may provide improved operating conditions. Our study was designed to test the hypothesis that hyperoxia, by improving oxygen delivery, would improve the margin of safety during hyperventilation.

Kennealy et al. ${ }^{12}$ have shown that, in dogs, hyperoxygenating the blood results in an increase in jugular venous bulb and brain tissue oxygen tension. However, others have shown reductions in CBF with hyperoxia in normocapnic piglets, ${ }^{13}$ ponies, ${ }^{14}$ infants ${ }^{15}$ and adults. ${ }^{16}$ This cerebral vasoconstriction may negate any potential beneficial effects of hyperoxia during hyperventilation. The effect of arterial hyperoxygenation on cerebral venous $\mathrm{O}_{2}$ content in anaesthetized patients during acute hyperventilation has not been fully investigated and is the purpose of this study.

We chose two levels of $\mathrm{PaCO}_{2}, 25 \mathrm{mmHg}$ and 30 $\mathrm{mmHg}$, to assess whether hyperoxygenation improves $\mathrm{SjvO}_{2}$ during moderate and marked hyperventilation. During hyperventilation to a $\mathrm{PaCO}_{2}$ of $25 \mathrm{mmHg}$, four patients had $\mathrm{SjvO}_{2}<50 \%$ at $\mathrm{PaO}_{2}$ of $100 \mathrm{mmHg}$ and two patients had $\mathrm{SjvO}_{2}<50$ at $\mathrm{PaO}_{2}$ of $250 \mathrm{mmHg}$. At a $\mathrm{PaCO}_{2}$ of $30 \mathrm{mmHg}$, only one patient had $\mathrm{SjvO}_{2}$ $<50 \%$ and this was at a $\mathrm{PaO}_{2}$ of $100 \mathrm{mmHg}$. There were no episodes of desaturation during hyperoxia at $\mathrm{PaO}_{2}$ of $400 \mathrm{mmHg}$ at either level of $\mathrm{PaCO}_{2}$. Although not applicable to the patients in this study, episodes of cerebral venous desaturation $\left(\mathrm{SjvO}_{2}<50 \%\right)$ have been shown to be common in patients with head injury even when receiving intensive care with advanced cardiovascular and intracranial monitoring. The observation that head-injured patients with cerebral venous desaturation had a higher mortality than those without such episodes highlights the potential benefit of detecting and treating such desaturation. ${ }^{16}$ It would appear that the most important factor controlling cerebral blood flow (CBF) is 
$\mathrm{PaCO}_{2}$, as shown by the higher $\mathrm{SjvO}_{2}, \mathrm{PjvO}_{2}$ and $\mathrm{CjvO}_{2}$ at the higher $\mathrm{PaCO}_{2}$ of $30 \mathrm{mmHg}(P<0.01)$. Nonetheless, in the 12 patients studied, hyperoxygenation was beneficial in reducing the incidence of cerebral venous oxygen desaturation during hyperventilation. Hyperoxygenation improved $\mathrm{CjvO}_{2}$ at both levels of $\mathrm{PaCO}_{2}(P$ $<0.05$ ). As the study was conducted during relatively steady-state anaesthetic and surgical conditions, this increase presumably reflects an increase in $\mathrm{O}_{2}$ delivery.

Does normobaric hyperoxygenation produce cerebral vasoconstriction in hypocapnic patients? To answer this question, we derived the predicted $\mathrm{CjvO}_{2}$ based on an unchanged $\mathrm{CBF}$ and an unchanged cerebral metabolic rate for oxygen $\left(\mathrm{CMRO}_{2}\right)$ and compared this to the actual measured $\mathrm{CjvO}_{2}$. We considered $\mathrm{PaO}_{2}$ of $100 \mathrm{mmHg}$ to be normoxia, and calculated the corresponding $\mathrm{AVDO}_{2}$. Assuming an unchanged $\mathrm{CMRO}_{2}$ (therefore an unchanged $\mathrm{AVDO}_{2}$ if CBF stays constant), we then calculated $\mathrm{CjvO}_{2}$ at $\mathrm{PaO}_{2}$ of 250 and $400 \mathrm{mmHg}$. We found the measured and the predicted $\mathrm{CjvO}_{2}$ to be almost identical with hyperoxia during hypocapnia. This suggests that, during steady state anaesthesia, when $\mathrm{CMRO}_{2}$ is presumed constant, there is no change in $\mathrm{CBF}$ when $\mathrm{PaCO}_{2}$ is constant and $\mathrm{PaO}_{2}$ is increased (Table III). Had there been any decrease in CBF with hyperoxia, the measured $\mathrm{CjvO}_{2}$ would have been lower than the predicted value. The Vmca determination in the five patients with transcranial Doppler monitoring supports this contention and is in agreement with recently published data on Vmca and hyperoxia. ${ }^{17,18}$ These findings indicate that the vasoconstrictive response to hyperoxia reported in other studies is abolished by hyperventilation, the anaesthetic conditions employed in this study, or both. It is likely that hypocapnia, even at $\mathrm{PaCO}_{2}$ of $30 \mathrm{mmHg}$, results in cerebral vasoconstriction that exceeds any vasoconstrictive effect of normobaric hyperoxia.

We conclude that hyperoxia during acute hyperventilation in the anaesthetized patient improves oxygen delivery to the brain as measured by increased cerebral venous oxygen content and saturation. This increase is seen without any apparent change in CBF. Hyperoxia should be considered for those patients in whom hyperventilation is contemplated and cerebral ischaemia is considered a risk.

\section{Acknowledgements}

The authors greatly acknowledge Dr. H. Richard Winn for his permission to perform this study on his patients, and Karen Rutherford for secretarial assistance.

\section{References \\ 1 Kety SS, Schmidt CF. The effect of active and passive hy-}

perventilation on cerebral blood flow, cerebral oxygen consumption, cardiac output, and blood pressure on normal young men. J Clin Invest 1946; 25: 107-19.

2 Wasserman AJ, Patterson JL Jr. The cerebral vascular response to reduction in arterial carbon dioxide tension. $\mathbf{J}$ Clin Invest 1961; 40: 1297-303.

3 Reivich MP, Cohen PJ, Greenbaum L. Alterations in the electroencephalogram of awake man produced by hyperventilation: effects of $100 \%$ oxygen at 3 atmospheres (absolute) pressure. Neurology 1966; 16: 304.

4 Plum F, Posner JB. Blood and cerebrospinal fluid lactate during hyperventilation. Am J Physiol 1967; 212: 864-70.

5 Plum F, Posner JB, Smith $W W$. Effect of hyperbarichyperoxic hyperventilation on blood, brain, and CSF lactate. Am J Physiol 1968: 215: 1240-4.

6 Nakajima S, Meyer JS, Amano T, Shaw T, Okabe T, Mortel $K F$. Cerebral vasomotor responsiveness during $100 \%$ oxygen inhalation in cerebral ischemia. Arch Neurol 1983; 40: 271-6.

7 Matta BF, Lam AM, Mayberg TS, Shapiro Y, Winn HR. A critique of the intraoperative use of jugular venous bulb catheters during neurosurgical procedures. Anesth Analg 1994 (in press).

8 Eng C, Lam AM, Mayberg TS, Lee C, Mathisen T. The influence of propofol with and without nitrous oxide on cerebral blood flow velocity and $\mathrm{CO}_{2}$ reactivity in humans. Anesthesiology 1992; 77: 872-9.

9 Cold GE. Does acute hyperventilation provoke cerebral oligemia in comatose patients with acute head injury? Acta Neurochir (Wien) 1989; 96: 100-6.

10 Muizelaar JP, Marmarou A, Ward JD, et al. Adverse effects of prolonged hyperventilation in patients with severe head injury: a randomized clinical trial. J Neurosurg 1991; 75: 731-9.

11 Elias-Jones AC, Punt JAG, Turnbull AE, Jaspan T. Management and outcome of severe head injuries in the Trent region 1985-90. Arch Dis Child 1992; 67: 1430-5.

12 Kennealy JA, McLennan JE, Loudon RG, McLaurin RL. Hyperventilation-induced cerebral hypoxia. Am Rev Respir Dis 1980; 122: 407-11.

13 Stiris T, Hansen TWR, Odden J-P, Mørkrid L, Bratlid D. Effect of light and hyperoxia on ocular blood flow in the newborn piglet. Biol Neonate 1989; 55: 191-6.

14 Busija DW, Orr JA, Rankin JHG, Liang HK, Wagerle LC. Cerebral blood flow during normocapnic hyperoxia in the unanesthetized pony. J Appl Physiol 1980; 48: 10-5.

15 Leahy FAN, Cates D, MacCullum M, Rigatto $H$. Effect of $\mathrm{CO}_{2}$ and $100 \% \mathrm{O}_{2}$ on cerebral blood flow in preterm infants. J Appl Physiol 1980; 48: 468-72.

16 Sheinberg M, Kanter MJ, Robertson CS, Contant CF, Narayan $R K$, Grossman $R G$. Continuous monitoring of jugular venous oxygen saturation in head-injured patients. J Neurosurg 1992; 76: 212-7. 
17 Fife CE, Powell MG, Sutton TE, Hanson S, StirlingMeyer $J$. TCD evaluation of the middle cerebral artery (MCA) during hyperbaric oxygenation (HBO) (Abstract). Stroke 1994; $25: 747$.

18 Ellingsen I, Hauge A, Nicolaysen $G$, Thoresen $M$, Wallфe $L$. Changes in human cerebral blood flow due to step changes in $\mathrm{P}_{\mathrm{AO}_{2}}$ and $\mathrm{P}_{\mathrm{ACO}}$. Acta Physiol Scand 1987; 129-157-63. 